\title{
DETECÇÃO DE DNA DE TOXOPLASMA GONDII EM ANIMAIS SILVESTRES NO ESTADO DA BAHIA
}

\section{Caroline Araújo da Silva ${ }^{1}$; Aristeu Vieira da Silva ${ }^{2}$ Taise Cristina Santa Barbara Silva Queizos ${ }^{3}$; Jadson Borges Nascimento ${ }^{4}$, e Priscilla Marcelly Vilanova ${ }^{5}$}

1.Bolsista PIBIC/FAPESB Graduanda em Ciências Biológicas, Universidade Estadual de Feira de Santana, e-mail: carol.adp@hotmail.com

2. Pró-Reitor de Pesquisa e Pós-Graduação , Universidade Estadual de Feira de Santana, e-mail: aristeuvsilva@uefs.br

3. Bolsista PIBIC/ CNPQ Graduanda em Ciências Biológicas , Universidade Estadual de Feira de Santana, email: taii.cristina@hotmail.com

4. Graduando em Ciências Biológicas, Universidade Estadual de Feira de Santana, e-mail: jadsonnascimento@outlook.com

5.Bolsista PIBIC/UEFS Graduando em Ciências Biológicas, Universidade Estadual de Feira de Santana, email: priscylla.marcelly@ hotmail.com

$\mathrm{P}$

PALAVRAS-CHAVE: Toxoplasma gondii, SILVESTRES, PCR

\section{INTRODUÇÃO}

A Mata Atlântica é um ecossistema que apresenta uma grande diversidade e um alto grau de endemismo tanto de animais quanto de plantas. O sul da Bahia, por exemplo, abriga uma enorme variedade de vegetais e animais endêmicos incluindo mamíferos ameaçados a extinção (Moura, 2003). Um dos problemas que tem agravado o processo de extinção é a fragmentação da Mata Atlântica que impede o fluxo gênico entre os organismos (Fahrig, 2003), além disso, a extensiva produção agrícola e pecuária induz o desmatamento para a plantação de monoculturas e plantação de pastagem respectivamente atingindo diretamente a fauna local (Magalhães, 2011).

As pesquisas sobre a importância dos animais silvestres na epidemiologia de algumas doenças infecciosas ainda são escassas (Franke et al., 2005).

$\mathrm{O}$ contato direto de seres humanos com animais silvestres traz diversas complicações como já foi citado anteriormente. O número de mortes de animais silvestres por doenças infecciosas vem crescendo ao longo dos anos e um dos agravantes é o contato destes com os animais domésticos.

Existem poucos estudos sobre a importância epidemiológica dos animais silvestres na transmissão da toxoplasmose e as pesquisas são em sua grande maioria realizadas apenas com exames sorológicos, esse trabalho teve por objetivo detectar $T$. gondii em tecidos de animais silvestres, além de extrair e amplificar DNA específico de T. gondii em tecidos de animais silvestres da Mata Atlântica na Bahia e comparar a frequência de positivos segundo os diferentes táxons e locais de coleta de amostras.

\section{MATERIAL E MÉTODOS OU METODOLOGIA (ou equivalente)}

A pesquisa aconteceu em duas regiões fisiográficas do Estado da Bahia, a mesorregião Sul Baiano, mais especificamente na Área de Proteção Ambiental do Pratigi, e a mesorregião do Recôncavo Baiano (Serra da Jibóia), onde houve coletas de animais durante pelo menos três excursões em 12 meses de execução do projeto. Dados meteorológicos foram obtidos pelas estações meteorológicas automáticas mais próximas 
a cada local através do site do Instituto Nacional de Meteorologia (http://www.inmet.gov.br/).

As capturas dos pequenos mamíferos foram feitas a partir de armadilhas de captura viva (tipo Sherman e Tomahawk) colocadas em transectos e dispostas no solo e no sub-bosque (entre 1,5 e $2 \mathrm{~m}$ ) e iscadas com uma mistura de fubá, banana, creme de amendoim e óleo de fígado de bacalhau. Os pequenos mamíferos capturados foram identificados, medidos e pesados. Foram utilizadas 50 armadilhas de cada tipo, que permaneceram ativas durante no mínimo sete dias consecutivos em cada uma das localidades, para um esforço amostral de 700 armadilhas para cada localidade. Os locais amostrados foram georreferenciados com GPS. Os procedimentos para coleta dos exemplares foram feitos seguindo os Princípios Éticos do Colégio Brasileiro de Experimentação Animal. Esta pesquisa se enquadra no projeto Pequenos mamíferos não-voadores do Sul da Bahia: conhecendo a mastofauna baiana, aprovado pelo CEUAUESC (Processo Nº 003/2013) e CEUA-UEFS e Licença ICMBio 17131-4.

Os indivíduos capturados tiveram dados biométricos registrados. Para cada espécie registrada, um casal-testemunho foi coletado, do qual foram retiradas as amostras de órgãos e tecidos. A eutanásia ocorreu por administração de quetamina e xilazina em dose que promoveu a anestesia e posterior morte dos animais, de acordo com os procedimentos sugeridos pelo Conselho Federal de Medicina Veterinária (CFMV, 2013). Fêmeas grávidas e lactantes não foram coletadas e a coleta de jovens também foi evitada ao máximo. Os indivíduos coletados foram tombados e depositados na Coleção de Mamíferos da Divisão de Mamíferos do Museu de Zoologia da UEFS (todos os procedimentos de captura e coleta de indivíduos estão previstos nas Autorizações para Atividades com Finalidade Científica nos 43948-1 e 41440-1). O indivíduo que morreu durante a captura e/ou manuseio, também foi tombado e depositado na referida coleção. Os procedimentos de coleta de amostras foram efetuados durante a taxidermia dos espécimes coletados: sangue foi colhido das veias jugulares e depositado em microtubos plásticos para posterior dessora e congelamento do soro. Estômago, intestinos, baço e fígado foram removidos e mantidos em álcool 70, enquanto que coração e encefálo foram mantidas em solução salina tamponada $\mathrm{pH}$ 7,2 sob refrigeração, até o dia de preparação das amostras para os exames.

Os órgãos dos animais foram encaminhados para o Laboratório de Análises Clínicas da UEFS onde foram macerados com o auxílio de cadinho e pistilo e foi adicionado PBS com o volume de $4 \mathrm{x}$ o peso da amostra e a seguir procedeu-se a extração de DNA genômico total utilizando-se kit de extração comercial. A reação em cadeia pela polimerase (PCR) para detecção de DNA específico de Toxoplasma gondii foi realizada pela nested-PCR para uma sequência repetitiva do genoma nuclear de $T$. gondii. Os iniciadores utilizados na PCR foram: Tox4 (CGCTGCAGGGAGGAAGACGAAAGTTG) e Tox5 (CGCTGCAGACACAGTGCATCTGGATT) nas condições de reação descritas por Homan et al (2000). O DNA amplificado final foi analisado por eletroforese em gel de agarose $2 \%$, corado com SyberGreen GelRed ${ }^{\mathrm{TM}}$ e visualizado sob luz ultravioleta. Para cada lote de ensaios foi incluído um controle positivo (DNA extraído da cepa RH de $T$. gondii) e um de controle negativo (água ultrapura). A frequência de positivos foi tabulada para cada espécie, família e ordem, sendo comparadas pelo método de Quiquadrado de Pearson ou $\mathrm{G}$ de Williams conforme a distribuição de frequências com os programas Epiinfo 7 e BioEstat 5.3 respectivamente. 
Dos 68 animais analisado, seis (8,82\%; IC95\%: 3,1-18,22) apresentaram resultados positivos na PCR.

Dos 20 animais da ordem Chiroptera analisados, dois (10,53\%; IC95\%:1,3033,14) (Figura1) apresentaram resultado positivo na PCR. As amostras positivas dessa ordem pertencem às Famílias Phyllostomidae e Emballonuridae respectivamente como é mostrado na figura 1 , sendo que um animal $(6,25 \%$; IC95\%: 0,16-30,25) representante da Família Phyllostomidae, desta foram capturados dois animais $(50,00 \%$; 95\%: 1,2698,74) da espécie Desmodus rotundus e um um animal (50,00\%; IC95\%: 1,26-98,74) representante da Família Emballonuridae e desta também foram capturados dois animais (50,00\%; IC95\%: 1,26-98,74) da espécie Rhynchonycteris sp. apresentaram resultados positivos na PCR.

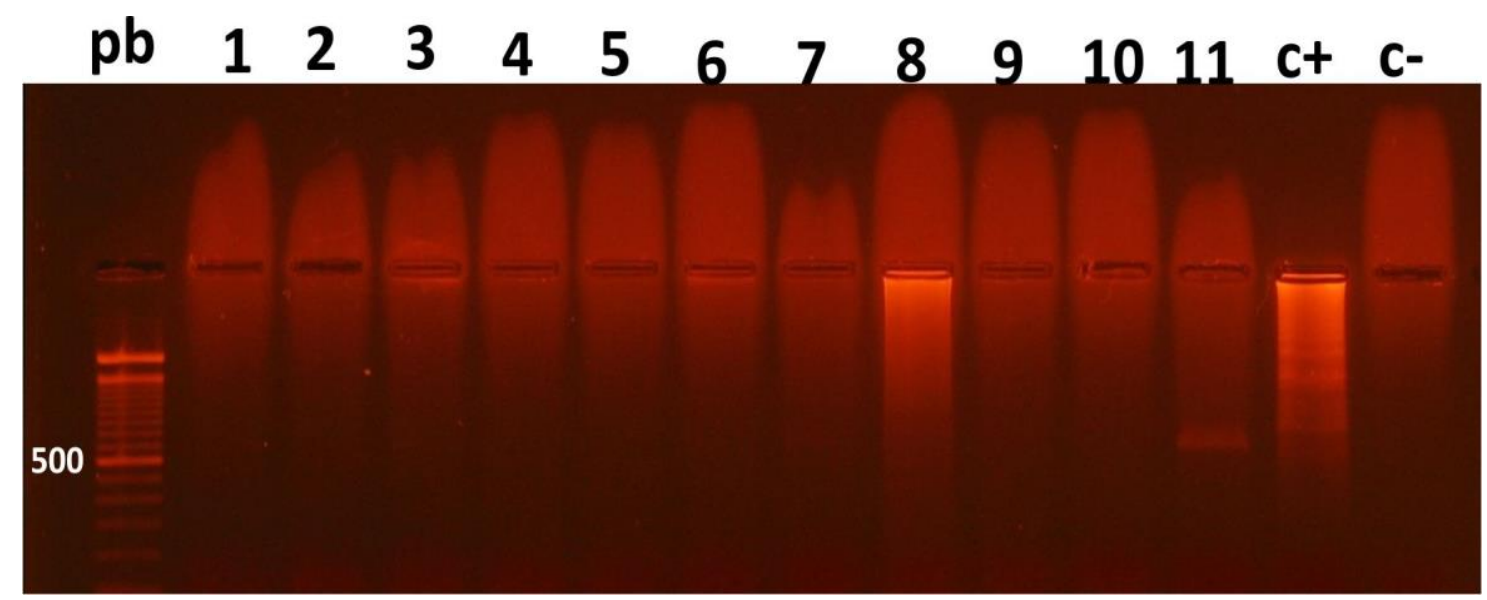

FIGURA 1- Eletroforese em gel de agarose a $2 \%$ de produtos de 529 pares de bases(pb) do gene de T.gondii obitidos do ensaio da nested de PCR de amostras de tecidos de morcegos ; Amostras 1 a 11; Controle positivo $(\mathrm{C}+)$; Controle negativo (C-); 8 e 11 amostras positivas da Ordem Chiroptera.

Em relação à ordem Didelphimorphia, todas as 19 amostras se mostraram negativas na PCR. São necessários maiores estudos moleculares sobre esses animais, pois as grandes partes das pesquisas estão relacionadas à sorologia anti-T. gondii, além disso, pesquisas nacionais e internacionais tem demostrado que esses animais estão mais susceptíveis a infecções em ambientes antropizados (Langoni, 2014).

Referente à ordem Rodendia, 30 animais foram analisados e quatro (13,33\%; IC95\%: 3,76-30,72) (Figura 2 e 3) apresentaram resultados positivos na PCR. As amostras positivas dessa ordem pertencem a Família Cricetidae como é ilustrado na figura 2 e 3, sendo que, quatro animais (13,33\%; IC95\%: 3,76-30,72) apresentaram resultados positivos na PCR. Nesta família foram os resultados foram encontrados em quatro espécies, sendo que de oito Akodon cursor 1 (11,11\%; IC95\%: 0,28-48,25) apresentaram DNA de T. gondii. Já na espécie Trinomys setosus, cf. Rhipidomys e Oxymycterus dasytrichus foram coletados um (100\%) animal de cada espécie e os mesmos foram positivos, como é ilustrado nas figuras 2 e 3 . 


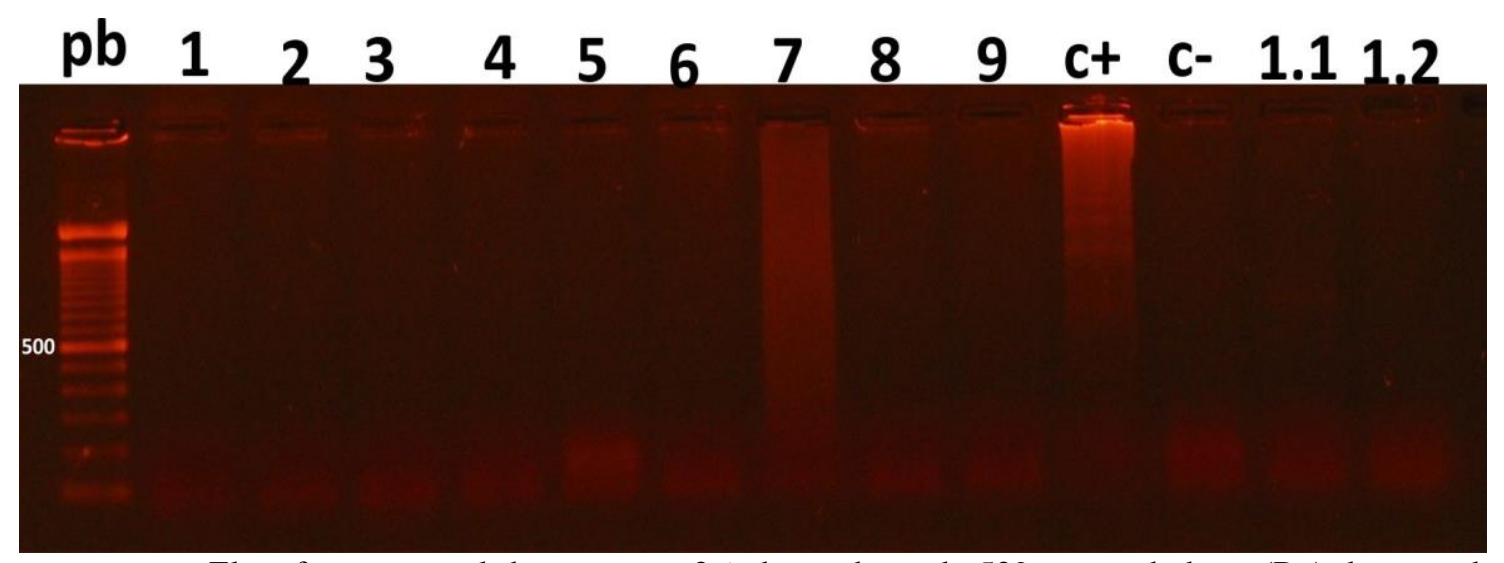

FIGURA 2- - Eletroforese em gel de agarose a $2 \%$ de produtos de 529 pares de bases(Bp) do gene de T.gondii, obitidos do ensaio da nested de PCR de amostras de tecidos de roedores; Amostras 1 a 9; Controle positivo $(\mathrm{C}+)$; Controle negativo $(\mathrm{C}-)$; 1.1 e 7 amostras positivas da Ordem Rodentia.

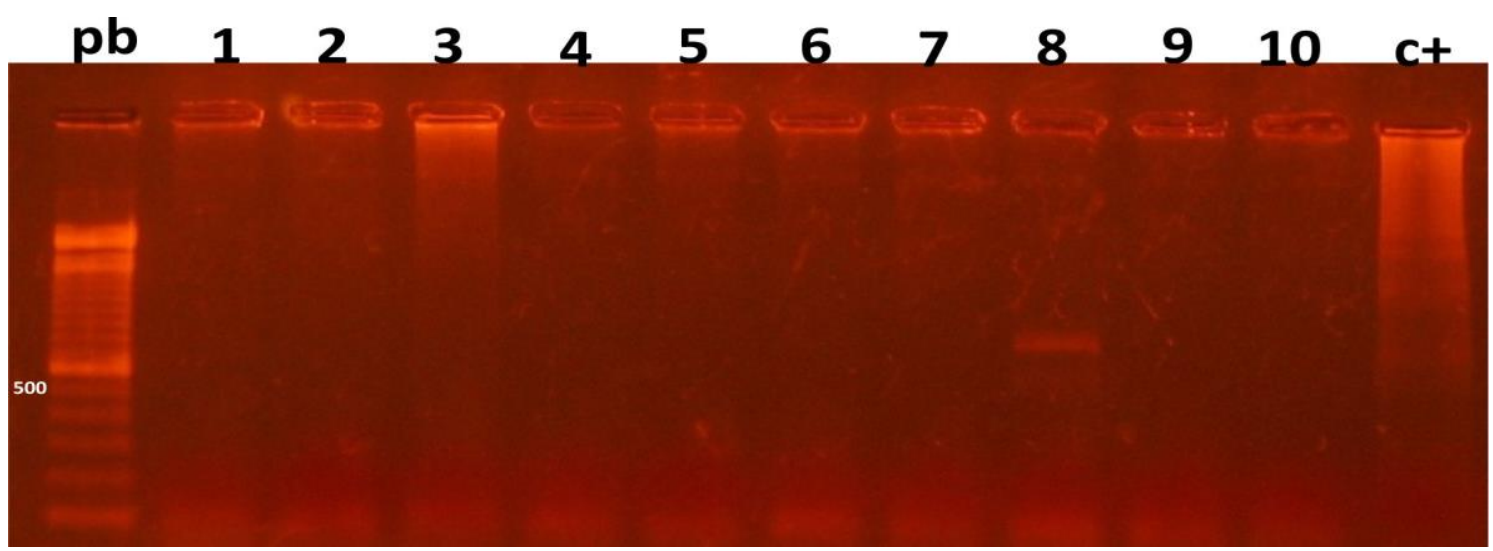

FIGURA 3- Eletroforese em gel de agarose a $2 \%$ de produtos de 529 pares de bases(Bp) do gene de

T.gondii obitidos do ensaio da nested de PCR de amostras de tecidos de roedores; Amostras 1 a 10; Controle positivo $(\mathrm{C}+) ; 3$ e 8 amostras positivas da Ordem Rodentia.

\section{CONSIDERAÇÕES FINAIS (ou Conclusão)}

A nPCR detectou a presença de DNA compatível com $T$. gondii em amostras de tecidos de animais silvestres da Mata Atlântica na mesorregião Sul da Bahia.

\section{REFERÊNCIAS}

FAHRIG, L. EFFECTS OF HABITAT FRAGMENTATION ON BIODIVERSITY. Annu. Rev. Ecol. Evol. Syst, v. 34, p. 487-515, 2003.

FRANKE, C. R. et al. Mata Atlântica e Biodiversidade _. 1. ed. Salvador: EdUFBA,2005.461p.

LAGOS, A. R. et al. Hotspot Brasileiro. Saúde e Ambiente, v. 2, n. 2, p. 35-45, 2007. LANGONI, H. Principais Zoonoses Em Mamíferos Selvagens. Veterinária e Zootecnia, v. 21, n. 1, p. 10-24, 2014.

MAGALHÃES, D. F. DE. Zoonoses e saúde pública: riscos da proximidade humana com a fauna silvestre. Ciênc. vet. tróp., v. 14, p. 1-9, 2011.

MOURA, R. T. DE. Distribuição E Ocorrência De Mamíferos Na Mata Atlântica Do Sul Da Bahia. Instituto de Estudos Sócio-Ambientais do Sul da Bahia e Conservation International do Brasil, p. 1-22, 2003.

UMETSU2, R. P. 1 \& F. Pequenos mamíferos não-voadores da Reserva Florestal do Morro Grande - distribuição das espécies e da diversidade em uma área de Mata

Atlântica. Biota Neotropica, v. 6, n. 2, p. 23, 2006. 